\title{
SEED MORPHOBIOMETRY AND GERMINATION OF Sesbania punicea (Cav.) Benth. AND Sesbania virgata (Cav.) Pers.
}

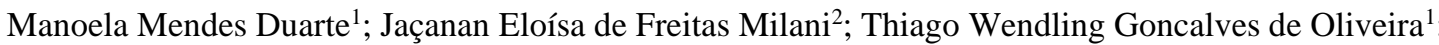 \\ Christopher Thomas Blum ${ }^{1}$; Antonio Carlos Nogueira ${ }^{1}$

\begin{abstract}
${ }^{1}$ Universidade Federal do Paraná, Programa de Pós-Graduação em Engenharia Florestal, Curitiba, Paraná, Brasil - manuflorestal@hotmail.com; thiagowendling@yahoo.com.br; ctblum.ufpr@gmail.com; nogueira@ufpr.br

${ }^{2}$ Universidade Federal de Mato Grosso, Departamento de Engenharia Florestal, Cuiabá, Mato Grosso, Brasil jacanan.milani@gmail.com;
\end{abstract}

Received for publication: 12/01/2018 - Accepted for publication: 05/02/2019

\begin{abstract}
Resumo
Morfobiometria de sementes e germinação de sesbania punicea (Cav.) Benth. e Sesbania virgata (Cav.) pers. Pertencentes a família Fabaceae, Sesbania punicia e $S$. virgata se caracterizam pelo elevado potencial ecológico para sua utilização na recuperação de áreas degradadas. O presente estudo teve por objetivo descrever as características físicas, morfobiométricas das sementes, as fases da germinação e o desenvolvimento inicial das plântulas de $S$. punicia e $S$. virgata, bem como o comportamento germinativo das sementes em diferentes temperaturas e substratos. Para a caracterização física das sementes foi determinado o peso de mil sementes, número de sementes por quilo, biomassa seca de mil sementes e o grau de umidade. Para avaliar o efeito do substrato e temperatura na germinação, conduziu-se o experimento sob um delineamento inteiramente casualizado, adotando-se um esquema fatorial 3 x 3, sendo três substratos (areia, vermiculita e papel mataborrão) e três temperaturas $\left(20,25\right.$ e $\left.30^{\circ} \mathrm{C}\right)$. Foram avaliados: porcentagem de germinação, índice de velocidade de germinação, tempo médio de germinação e índice de sincronização. S. punicea apresentou 13.243 e $S$. virgata 14.414 sementes por quilograma, com grau de umidade de 14,5 e 7,9 \%, respectivamente. As duas espécies apresentam morfobiometria e desenvolvimento de plântulas semelhantes. Para S. punicea o substrato papel mata-borrão e a temperatura de $25{ }^{\circ} \mathrm{C}$ foram mais eficientes para a germinação. Para S. virgata todos os tratamentos se mostraram efetivos para a germinação.
\end{abstract}

Palavras-chave: espécies nativas; recuperação de áreas degradadas; IVG; Fabaceae.

\begin{abstract}
Belonging to the family Fabaceae, Sesbania punicia and S. virgata are characterized by their ecological potential in the recovery of degraded areas. The present study aimed to describe the physical, morphobiometric characteristics of seeds, the germination phases and the initial development of $S$. punicia and S. virgata seedlings, as well as the germination behavior of seeds at different temperatures and substrates. For the physical characterization of seeds, the weight of one thousand seeds, number of seeds per kilogram, dry biomass of one thousand seeds and the moisture content were determined. To evaluate the effect of substrate and temperature on germination, the experiment was conducted in a completely randomized design, using a $3 \times 3$ factorial scheme, three substrates (sand, vermiculite and blotting paper) and three temperatures $\left(20,25\right.$ and $\left.30{ }^{\circ} \mathrm{C}\right)$. The following factors were evaluated: germination percentage, germination speed index, mean germination time and synchronization index. S. punicea presented 13,243 seeds and S. virgata presented 14,414 seeds per kilogram, with moisture content of 14.5 and $7.9 \%$, respectively. Both species present similar morphobiometry and seedling development. For S. punicea, the blotting paper substrate and the temperature of $25^{\circ} \mathrm{C}$ were most efficient for germination. For $S$. virgata, all treatments were effective for germination.

Key words: native species; recovery of degraded areas; GSI; Fabaceae.
\end{abstract}

\section{INTRODUCTION}

Fabaceae presents countless species with great economic and ecological potential. In an ecological context, this family is used to recover degraded areas, as many species affect nitrogen-fixing bacteria, allowing them to maintain adequate levels in the soil, which helps in the establishment and development of plants (FLORENTINO; MOREIRA, 2009).

Sesbania punicea (Cav.) Benth. and Sesbania virgata (Cav.) Pers. are legumes of the subfamily Papilionoideae, characterized as bushes and occur naturally in the Southern, Southeastern, Midwestern and Northeastern regions of Brazil. In general, they are found in riverine vegetation, and are associated with the initial stages of ecological succession (POTOMATI; BUCKERIDGE, 2002).

These species are highly tolerant to environments with low oxygenation, showing their potential and ability to restore riparian forests (ALLEN; ALLEN, 1981). Studies developed with the genus Sesbania indicated

FLORESTA, Curitiba, PR, v. 49, n. 4, p. 661 - 670, out/dez 2019.

Duarte, M. M. et.al.

ISSN eletrônico 1982-4688

DOI: $10.5380 /$ rf.v49 i4.57410 
that $S$. virgata presented important results regarding carbon immobilization, due to its rapid growth and fast and efficient fixation of large amounts of carbon, being a feature of interest for the processes of carbon sequestration, ecological succession and restoration (BUCKERIDGE; MORTARI; MACHADO, 2007).

Despite the ecological potential of Sesbania species, further studies addressing the morphological description of seeds, seedlings and their germination characteristics are still needed. Thus, knowledge about morphological characteristics of seeds and the germination and development stages of young plants provides information that can help identify species and in studies about natural regeneration and recovery of degraded areas (HALISKI et al., 2013). The germination test is the most widely used method for determining germination potential, since it determines the viability of seeds under previously established conditions (OLIVEIRA et al., 2008), making inferences about the potential seedling production and their use in the field.

According to the Rios et al. (2016), biometric studies of fruits and seeds are developed to complement morphological studies, which help determine the ecological aspects of species, and obtain subsidies for studies about dispersal, establishment and development of seedlings in native forests. Furthermore, biometric characters differentiate species within the same genus, identify genetic variability within a population of the same species, and analyze the relationships between this variability and environmental factors (GONÇALVES et al., 2013).

Temperature and substrate are basic components of laboratory germination tests and, in general, seeds have variable performance when subjected to different conditions of these factors (MONDO et al., 2008). Due to this variation in seed physiological response, it is important and advisable to study the influence of temperature and substrates on the germination of forest species, which provides input for further analyses and studies (GUEDES et al., 2009).

Therefore, the present study aimed to describe the physical morphobiometric characteristics of seeds, the germination phases and initial development of $S$. punicia and $S$. virgate seedlings, as well as study the germinative behavior of seeds submitted to different temperatures and substrates.

\section{MATERIALS AND METHODS}

\section{Physical analysis of seeds and morphological characterization of seeds, seedlings and germination phases}

Fruits were collected from matrix trees located in a remnant known as "Capão do Cifloma", located at at Campus Jardim Botânico of the Universidade Federal do Paraná, urban perimeter of Curitiba-PR. After collecting fruits, the seeds were manually removed, packaged in polyethylene containers and kept in a cold chamber $(5 \pm$ $3{ }^{\circ} \mathrm{C}$ and $55 \%$ relative humidity) until experiments were carried out. All analyses were performed at the Laboratório de Sementes Florestais do Departamento de Ciências Florestais da Universidade Federal do Paraná, in Curitiba, Paraná.

For physical characterization of seeds, the weight of one thousand seeds, the number of seeds per kilo, and the moisture degree of seeds were determined, adopting the methodology described in the Rules for Seed Analysis (BRASIL, 2009). The weight of a thousand seeds was obtained from eight subsamples of 100 seeds each, weighed on a precision scale $(0.001 \mathrm{~g})$ and the number of seeds per kilo was calculated from the weight of 1,000 seeds. The moisture degree was obtained from two $\sim 5 \mathrm{~g}$ samples, dried in a forced ventilation oven at $105{ }^{\circ} \mathrm{C} \pm 3$ ${ }^{\circ} \mathrm{C}$, for 24 hours. The dry biomass of 1,000 seeds was calculated based on the moisture degree and the weight of 1,000 seeds.

For biometric characterization, 50 seeds were randomly taken from the total sample. Length, width and thickness were measured with a precision caliper, and the length was measured from the base to the apex, while the width and thickness were measured from the median line of seeds. For the morphological characterization of germination and seedling phases, 50 seeds were used, which were scarified and sown in plastic gerbox boxes $(11 \times 11 \times 3.5 \mathrm{~cm})$ with blotting paper substrate, kept in Biochemical Oxygen Demand (B.O.D.) chamber at a constant temperature of $25^{\circ} \mathrm{C}$ and a photoperiod of 24 hours. Evaluations were performed every day after the first seed germinated and were considered seedlings when protophilus were fully formed.

The seed morphology of both species was described by characterizing the external and internal aspects. The following external factors were observed: coloration, texture, integument consistency, shape, edge, hilum and micropyle position. To study the internal morphology, the seeds were placed in hot water (approximately $95^{\circ} \mathrm{C}$ ) and left to hydrate for approximately 30 minutes and, from cross-sectional and longitudinal sections, the following 
characteristics were observed and described: endosperm type and color; type, position and shape of the embryo; shape and consistency of cotyledons; and the position of the hypocotyl-radicle axis.

At all stages from germination to seedling formation, the type of germination, radicle and root, hypocotyl, epicotyl and cotyledon were described and presented. The observations to describe the morphology of seeds and seedlings were done visually and with a stereo microscope (Olympus SZ40), from well-developed and representative material of each phase and presented as digital photographs (Digital camera Sony DSC-S750).

\section{Influence of substrate and temperature on germination}

To evaluate the effect of substrate and temperature on germination, this experiment was conducted using a completely randomized design, adopting a $3 \times 3$ factorial scheme, with three substrates (sand, vermiculite and blotting paper) and three temperatures $\left(20,25\right.$ and $\left.30^{\circ} \mathrm{C}\right)$. Five replicates of 35 seeds were used for each treatment, which were sown in the substrates, placed in gerbox boxes sterilized with $70 \%$ alcohol and put in B.O.D. chamber, under constant white light. Seed dormancy was overcome by mechanical scarification (manual with sandpaper) at the top and opposite to the embryo axis.

The sand was standardized in a $0.8 \mathrm{~mm}$ mesh sieve, washed and oven sterilized at $200^{\circ} \mathrm{C}$ for two hours, using 100 grams for each gerbox, moistened with $35 \mathrm{ml}$ of distilled water ( $60 \%$ retention capacity). For the vermiculite substrate (medium granulometry), 20 grams of substrate were used in each gerbox with $70 \mathrm{ml}$ of water. For the paper substrate, blotting paper moistened with $7 \mathrm{ml}$ of distilled water was used. Whenever necessary, water was added in all substrates.

The germination criterion used was primary root protrusion with a length equal to or greater than $2 \mathrm{~mm}$. After the first germinated seed, evaluations were performed daily until germination stabilized for three consecutive days. Germination percentage, germination speed index (GSI) proposed by Maguire (1962), mean germination time (MTG) proposed by Laboriau (1983) and synchronization index were calculated.

The data was submitted to the Bartlett test to verify homogeneity of variances. Next, an analysis of variance (ANOVA) was performed at 95\% probability and for comparison of treatment mean the Tukey test was performed.

\section{RESULTS}

\section{Physical analysis and morphological characterization of seeds, seedlings and germination phases}

The physical and biometric characteristics of the seeds of both species studied are described in Table 1 . Both species had similar values of length, width, thickness, weight and dry biomass of 1,000 seeds, but the moisture degree of S. punicea was twice as high as that of S. virgata.

Tabela 1. Características físicas e biométricas das sementes de Sesbania punicea e Sesbania virgata.

Table 1. Physical and biometric characteristics of Sesbania punicea and Sesbania virgata seeds.

\begin{tabular}{|c|c|c|c|c|c|c|}
\hline \multirow{2}{*}{ Determinations } & \multicolumn{3}{|c|}{ Sesbania punicea } & \multicolumn{3}{|c|}{ Sesbania virgata } \\
\hline & Minimum & Mean & Maximum & Minimum & Mean & Maximum \\
\hline Seed length (mm) & 6.10 & $6.9 \pm 0.40$ & 8.04 & 5.03 & $6.5 \pm 0.62$ & 7.84 \\
\hline Seed width (mm) & 3.93 & $4.2 \pm 0.14$ & 4.52 & 3.77 & $4.3 \pm 0.27$ & 4.95 \\
\hline Seed thickness (mm) & 2.97 & $3.4 \pm 0.17$ & 3.61 & 2.82 & $3.2 \pm 0.24$ & 4.43 \\
\hline Weight of 1,000 seeds $(\mathrm{g})$ & & 75.5 & & & 69.4 & \\
\hline Number of seeds per kilo & & 13.243 & & & 14.414 & \\
\hline Moisture degree (\%) & & 14.5 & & & 7.9 & \\
\hline Dry biomass of 1,000 seeds $(\mathrm{g})$ & & 64.5 & & & 63.9 & \\
\hline
\end{tabular}

The mean values of length were $6.9 \pm 0.40$ and $6.5 \pm 0.62 \mathrm{~mm}$, width: $4.2 \pm 0.14$ and $4.3 \pm 0.27 \mathrm{~mm}$ and thickness: $3.4 \pm 0.17$ and $3.2 \pm 0.24$ for S. punicea and S. virgate, respectively. According to deviation values, variation of all characteristics was higher for $S$. virgata. The external and internal morphology of the seeds of both species is shown in Figure 1.

FLORESTA, Curitiba, PR, v. 49, n. 4, p. 661 - 670, out/dez 2019. 


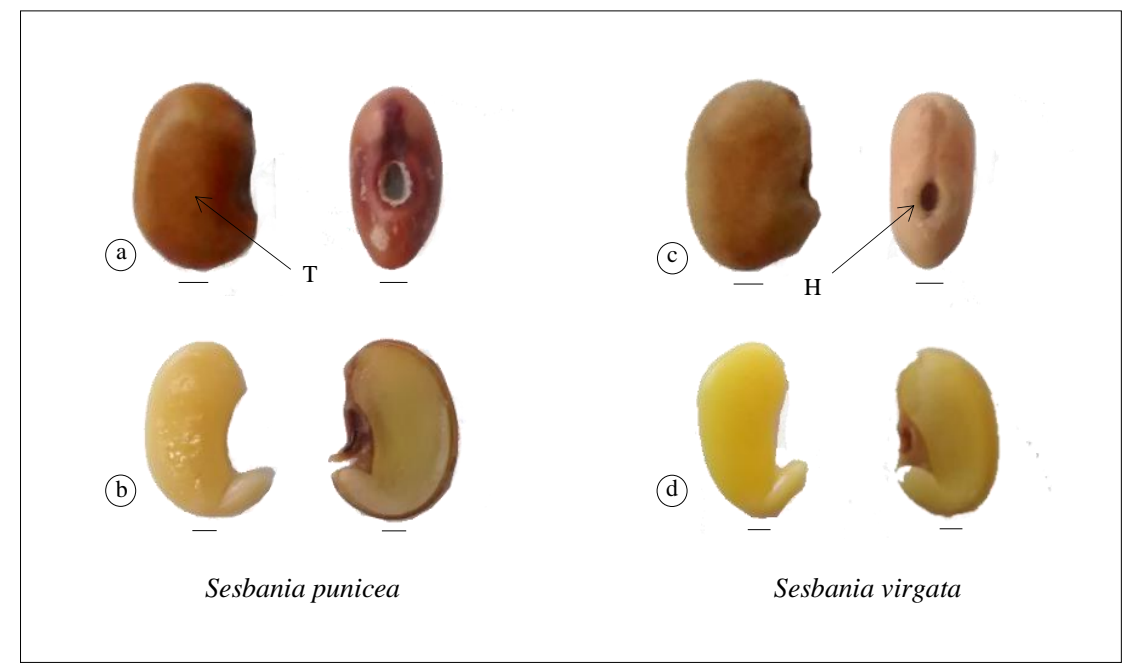

Figura 1. Morfologia externa e interna das sementes de Sesbania punicea e Sesbania virgata. Aspecto externo, demonstrando tegumento $(\mathrm{T})$ e o hilo $(\mathrm{H})(\mathrm{a}, \mathrm{c})$; Corte transversal das sementes (b, d); Embrião (b, d). Barra $=0,1 \mathrm{~cm}$.

Figure 1. External and internal morphology of Sesbania punicea and Sesbania virgate seeds. External aspect, showing tegument $(\mathrm{T})$ and hilum $(\mathrm{H})(\mathrm{a}, \mathrm{c})$; Cross section of seeds $(\mathrm{b}, \mathrm{d})$; Embryo $(\mathrm{b}, \mathrm{f})$. Bar $=0.1 \mathrm{~cm}$.

Externally, the seeds of S. punicea have a smooth, hard, waterproof and dark brown tegument. The hilum has an ovoid shape, dark brown, with central fissure, and the hilar region is noticeably larger than that of S. virgata. The micropyle was not observed and the raphe is presented as a line, coming out of the hilum and ending shortly before the seed base with a higher region, presenting a darker color than the rest of the seed.

In the internal morphology of $S$. punicea seeds, the inner part of the tegument has a spongy consistency, with thickness approximately $1 / 3$ the size of the endosperm and voluminous in the region of the hilum. The seed is albuminous, that is, the endosperm is a very clear, cream color that is almost transparent and has a gelatinous consistency (seeds hydrated in boiling water). The endosperm envelopes the entire embryo, presenting a thinner layer at the edges of cotyledons. The embryo is axial curved, continuous and cotyledonary. The cotyledon are cream colored, thick and equal, with edges that are slightly folded towards the inside of the embryo, and short and inflected hypocotyl-radicle axis (Figure 1).

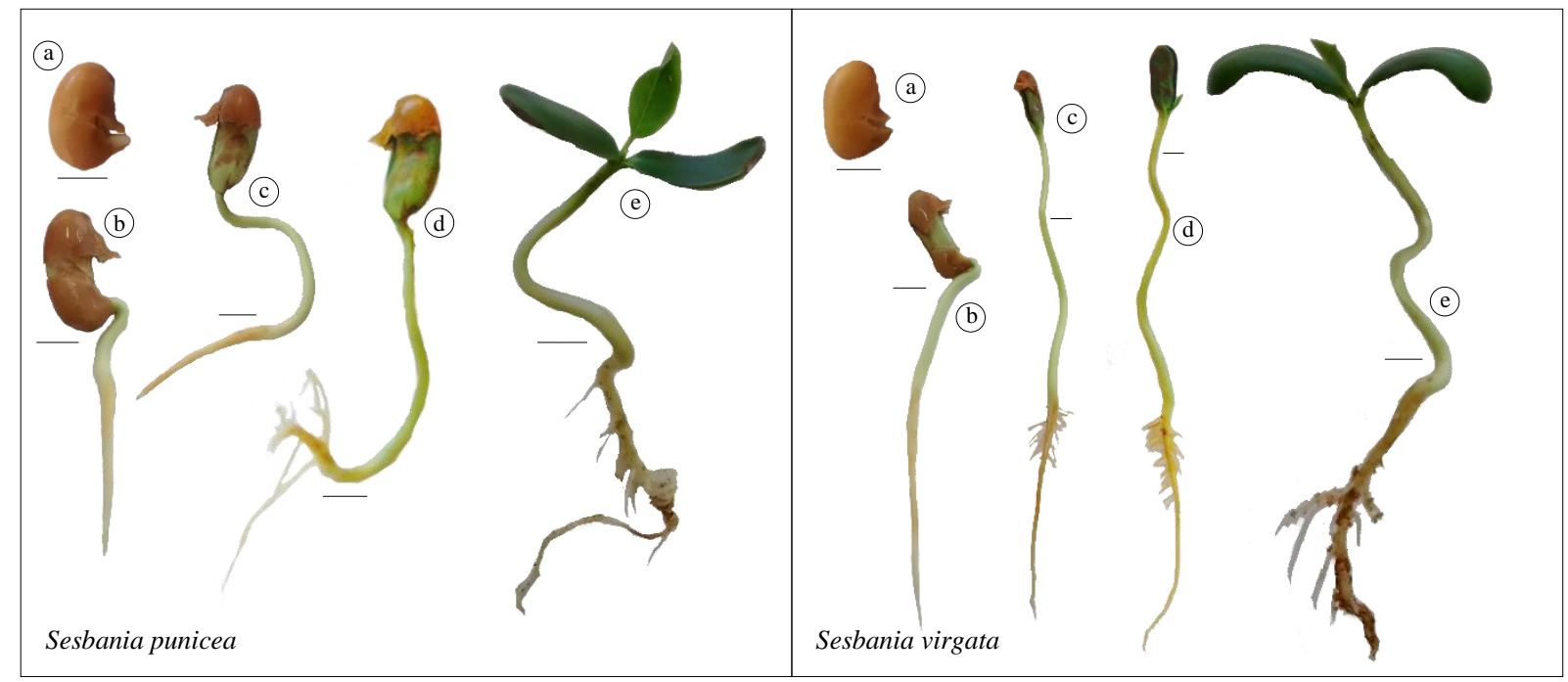

Figura 2. Morfologia, desenvolvimento e fases da germinação de Sesbania punicea e Sesbania virgata. S. punicea: início da germinação, quarto, sétimo, oitavo e $13^{\circ}$ dia (a, b, c, d, e, respectivamente). S. virgata: início da germinação, quarto, sétimo, nono e $13^{\circ}$ dia (a, b, c, d, e, respectivamente). Barra $=1 \mathrm{~cm}$.

Figure 2. Morphology, development and germination stages of Sesbania punicea and Sesbania virgata. S. punicea: beginning of germination, fourth, seventh, eighth and thirteenth day (a, b, c, d, e, respectively). $S$. virgata: beginning of germination, fourth, seventh, ninth and thirteenth day (a, b, c, d, e, respectively). Bar $=1 \mathrm{~cm}$. 
Externally the seeds of $S$. virgata have a hard, smooth, waterproof and light brown tegument. The hilum is located laterally, in the middle portion of the seed, with an ovoid shape, dark brown color and central fissure. The micropyle is circular with reduced size that is almost imperceptible to the naked eye. A short raphe can be seen externally, coming out of the hilum to the base of the seed, ending in a higher region and presenting a slightly darker color.

Regarding the internal tegument, the characteristics of the endosperm, embryo and cotyledon, there were no significant morphological differences between the two species, and the seeds of $S$. virgata were morphology equal to S. punicea (Figure 1).

As for the characterization of germination, both species are similar, and for S. punicea, germination began after the 3rd day of sowing, with elevation of the hypocotyl and radicle expansion extending until the 13th day, while the germination of $S$. virgata began on the 2 nd day and extended until the 9 th day. The two species present phanerocotyledonary germination, since the cotyledons emerged from the seed tegument and expanded. The phases of germination and seedling development are presented in Figure 2.

The seedling morphology is also similar for the species, with a long hypocotyl compared to the epicotyl, cream-colored at the base and greenish towards the apex. The cotyledons are foliate, opposites, membranous, dark green, with full and rounded margins at the apex (Figure 2). Seedling development occurred quickly and homogeneously, however, seedlings of S. virgata developed and grew faster when compared to those of S. punicea (Figure 2).

\section{Influence of different substrates and temperatures on germination}

The results of $S$. punicea indicated that for the germination percentage (G), germination speed index (GSI) and synchronization index $(\mathrm{E})$ there were no significant interactions between temperature and substrate, however, there was a significant difference between treatments according to the Tukey test. For mean germination time (MGT), the interaction was significant (Table 2).

For $S$. virgate, there was no statistical difference between the substrates and temperatures for germination percentage. For germination speed index, the interaction was not significant, but the results showed significant differences between temperatures and substrates. The synchronization index showed a significant difference at 95\% probability for evaluated temperatures only. For mean germination time, the interaction between substrate and temperature was significant (Table 2).

Tabela 2. Análise de variância para porcentagem de germinação (G), índice de velocidade de germinação (IVG), índice de sincronização (E) e tempo médio de germinação (TMG) de sementes de Sesbania punicea e Sesbania virgata.

Table 2. Variance analysis for percentage of germination (G), germination speed index (GSI), synchronization index (E) and mean germination time (MGT) of Sesbania punicea and Sesbania virgata seeds.

\begin{tabular}{|c|c|c|c|c|c|c|}
\hline \multirow{2}{*}{ Species } & \multirow{2}{*}{ S.V. } & \multirow{2}{*}{ D.F. } & \multicolumn{4}{|c|}{ Mean Square } \\
\hline & & & $\mathrm{G}$ & GSI & $\mathrm{E}$ & MGT \\
\hline \multirow{5}{*}{ 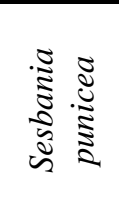 } & Substrate & 2 & $568.89^{*}$ & $5.55^{*}$ & $0.79^{* *}$ & $9.97^{* *}$ \\
\hline & Temperature & 2 & $411.61^{*}$ & $31.00^{* *}$ & $3.16^{* *}$ & $36.53^{* *}$ \\
\hline & Interaction & 4 & $281.81^{\mathrm{ns}}$ & $3.02^{\mathrm{ns}}$ & $0.19^{\mathrm{ns}}$ & $0.87^{*}$ \\
\hline & Mean & - & 62.15 & 5.19 & 1.75 & 4.85 \\
\hline & C.V. $(\%)$ & - & 17.64 & 24.73 & 15.87 & 11.34 \\
\hline \multirow{5}{*}{ 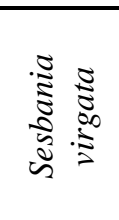 } & Substrate & 2 & $6.53^{\mathrm{ns}}$ & $3.24^{* *}$ & $0.15^{\mathrm{ns}}$ & $0.78^{* * *}$ \\
\hline & Temperature & 2 & $28.30^{\mathrm{ns}}$ & $22.80^{* *}$ & $0.78^{* *}$ & $5.18^{* *}$ \\
\hline & Interaction & 4 & $38.09^{\mathrm{ns}}$ & $0.50^{\mathrm{ns}}$ & $0.13^{\mathrm{ns}}$ & $0.29^{*}$ \\
\hline & Mean & - & 94.28 & 8.53 & 1.36 & 4.07 \\
\hline & C.V. $(\%)$ & - & 4.92 & 8.52 & 21.93 & 8.07 \\
\hline
\end{tabular}

S.V.: Source Variation; C.V .(\%): Variation coefficient; D.F.: Degrees of freedom; ${ }^{* *}$ Significant at $1 \%$ probability level $(\mathrm{p}<0.01) ;{ }^{*}$ Significant at a $5 \%$ probability level $\left(0.01=\langle\mathrm{p}<0.05){ }^{\text {ns }}\right.$ : Not significant $(\mathrm{p}>=0.05)$. 
Among the substrates tested with $S$. punicea, the blotting paper differed statistically from the vermiculite, presenting the highest germination percentage. Among the temperatures, the $25{ }^{\circ} \mathrm{C}$ treatment was more efficient for germination of the species, with a statistically higher mean than the $30^{\circ} \mathrm{C}$ treatment (Table 3 ).

Tabela 3. Médias para porcentagem de germinação (G), índice de velocidade de germinação (IVG), índice de sincronização (E) e tempo médio de germinação (TMG) de sementes de Sesbania punicea submetidos a diferentes substratos e temperaturas.

Table 3. Percentage of germination (G), germination speed index (GSI), synchronization index (E) and mean germination time (MGT) of Sesbania punicea seeds submitted to different substrates and temperatures.

\begin{tabular}{|c|c|c|c|c|}
\hline \multirow{2}{*}{ Substrate } & \multicolumn{4}{|c|}{ TEMPERATURE ${ }^{\circ} \mathrm{C}$} \\
\hline & 20 & 25 & 30 & Mean \\
\hline \multicolumn{5}{|c|}{$\mathrm{G}$} \\
\hline Sand & 58.86 & 72.57 & 52.00 & $61.14 \mathrm{ab}$ \\
\hline Vermiculite & 52.00 & 58.29 & 59.43 & $56.57 \mathrm{~b}$ \\
\hline Paper & 75.43 & 71.43 & 59.43 & $68.76 \mathrm{a}$ \\
\hline Mean & $62.10 \mathrm{ab}$ & $67.43 \mathrm{a}$ & $56.95 \mathrm{~b}$ & \\
\hline \multicolumn{5}{|c|}{ GSI } \\
\hline Sand & 3.18 & 6.77 & 5.97 & $5.31 \mathrm{ab}$ \\
\hline Vermiculite & 3.68 & 6.35 & 7.19 & $5.74 \mathrm{a}$ \\
\hline Paper & 3.75 & 4.73 & 5.14 & $4.54 \mathrm{~b}$ \\
\hline Mean & $3.54 \mathrm{~b}$ & $5.95 \mathrm{a}$ & $6.10 \mathrm{a}$ & \\
\hline \multicolumn{5}{|c|}{$\mathrm{E}$} \\
\hline Sand & 2.25 & 1.77 & 1.52 & $1.85 \mathrm{a}$ \\
\hline Vermiculite & 2.33 & 1.83 & 1.65 & $1.93 \mathrm{a}$ \\
\hline Paper & 2.14 & 1.55 & 0.81 & $1.50 \mathrm{~b}$ \\
\hline Mean & $2.24 \mathrm{a}$ & $1.71 \mathrm{~b}$ & $1.32 \mathrm{c}$ & \\
\hline \multicolumn{5}{|c|}{ MGT } \\
\hline Sand & 6.94 a A & $4.01 \mathrm{~b} \mathrm{~B}$ & $3.52 \mathrm{ab} \mathrm{B}$ & 4.82 \\
\hline Vermiculite & $5.46 \mathrm{~b} \mathrm{~A}$ & $3.55 \mathrm{~b} \mathrm{~B}$ & $3.13 \mathrm{~b} \mathrm{~B}$ & 4.05 \\
\hline Paper & 7.38 a A & 5.54 a B & $4.11 \mathrm{a} \mathrm{C}$ & 5.68 \\
\hline Mean & 6.59 & 4.37 & 3.59 & \\
\hline
\end{tabular}

Mean followed by the same lowercase letter in the column and capitalized letter in the row do not differ by the Tukey test at 5\% probability.

Regarding the GSI, the vermiculite substrate was more efficient, with a statistically higher germination speed than the blotting paper. Among the temperatures, the $20{ }^{\circ} \mathrm{C}$ treatment presented the lowest GSI and was statistically lower than the temperatures of $25^{\circ} \mathrm{C}$ and $30^{\circ} \mathrm{C}$.

For interpretation of the means of synchronization index, it is important to highlight that the lower the value, the more synchronized germination is in relation to time. Thus, the blotting paper substrate was more efficient at synchronizing the germination of $S$. punicea and statistically superior to the other substrates. For temperatures, the $30^{\circ} \mathrm{C}$ treatment proved to be the best at synchronizing germination (Table 3).

The best combinations for mean germination time of $S$. punicea are the temperatures of $25^{\circ} \mathrm{C}$ and $30{ }^{\circ} \mathrm{C}$, combined with sand or vermiculite substrates, as they were statistically superior to the other combinations, since the germination time was shorter when the observed value was lower (Table 3).

For germination percentage of $S$. virgata, no statistical differences were observed between the substrates and temperatures tested, and for all treatments the mean germination was above $90 \%$. For the GSI, the sand substrate promotes faster germination and, among the temperatures, $30^{\circ} \mathrm{C}$ is most efficient at accelerating the germination process (Table 4).

Tabela 4. Médias para porcentagem de germinação (G), índice de velocidade de germinação (IVG), índice de sincronização (E) e tempo médio de germinação (TMG) de sementes de Sesbania virgata submetidos a diferentes substratos e temperaturas. 
Table 4. Percentage of germination (G), germination speed index (GSI), synchronization index (E) and mean germination time (MGT) of Sesbania virgata seeds submitted to different substrates and temperatures.

\begin{tabular}{|c|c|c|c|c|}
\hline \multirow{3}{*}{ SUBSTRATE } & \multicolumn{4}{|c|}{ TEMPERATURE ${ }^{\circ} \mathrm{C}$} \\
\hline & 20 & 25 & 30 & Mean \\
\hline & \multicolumn{2}{|c|}{$\mathrm{G}$} & & \\
\hline Sand & 91.43 & 92.57 & 97.71 & $93.90 \mathrm{a}$ \\
\hline Vermiculite & 95.43 & 94.29 & 92.00 & $93.90 \mathrm{a}$ \\
\hline Paper & 94.86 & 92.57 & 97.71 & $95.05 \mathrm{a}$ \\
\hline \multirow[t]{2}{*}{ Mean } & $93.90 \mathrm{a}$ & $93.14 \mathrm{a}$ & $95.81 \mathrm{a}$ & \\
\hline & \multicolumn{2}{|c|}{ GSI } & & \\
\hline Sand & 7.63 & 9.41 & 9.94 & $8.99 \mathrm{a}$ \\
\hline Vermiculite & 6.99 & 8.91 & 9.79 & $8.56 \mathrm{ab}$ \\
\hline Paper & 7.04 & 7.90 & 9.25 & $8.06 \mathrm{~b}$ \\
\hline \multirow[t]{2}{*}{ Mean } & $7.22 \mathrm{c}$ & $8.74 \mathrm{~b}$ & $9.66 \mathrm{a}$ & \\
\hline & \multicolumn{2}{|c|}{$\mathrm{E}$} & & \\
\hline Sand & 1.60 & 1.26 & 1.22 & $1.35 \mathrm{a}$ \\
\hline Vermiculite & 1.75 & 1.32 & 1.31 & $1.46 \mathrm{a}$ \\
\hline Paper & 1.44 & 1.45 & 0.90 & $1.26 \mathrm{a}$ \\
\hline \multirow[t]{2}{*}{ Mean } & $1.60 \mathrm{a}$ & $1.34 \mathrm{ab}$ & $1.14 \mathrm{~b}$ & \\
\hline & \multicolumn{2}{|c|}{ MGT } & & \\
\hline Sand & $4.36 \mathrm{~b} \mathrm{~A}$ & $3.58 \mathrm{~b} \mathrm{~B}$ & $3.60 \mathrm{a} \mathrm{B}$ & 3.85 \\
\hline Vermiculite & $5.01 \mathrm{a} \mathrm{A}$ & $3.82 \mathrm{ab} B$ & $3.42 \mathrm{a} \mathrm{B}$ & 4.08 \\
\hline Paper & 4. $84 \mathrm{ab} \mathrm{A}$ & $4.27 \mathrm{a} \mathrm{B}$ & 3. $80 \mathrm{a} \mathrm{B}$ & 4.30 \\
\hline Mean & 4.74 & 3.89 & 3.61 & \\
\hline
\end{tabular}

Mean followed by the same lowercase letter in the column and capitalized letter in the row do not differ by the Tukey test at 5\% probability.

There were statistical differences between temperatures for the synchronization index, where $30^{\circ} \mathrm{C}$ presented the best synchronization and was superior to the treatment with $20^{\circ} \mathrm{C}$. Regarding the MGT, there was a significant interaction between the treatments and the most efficient combination of $25^{\circ} \mathrm{C}$ with sand substrate presented the lowest germination times for S. virgata seeds (Table 4).

\section{DISCUSSION}

Understanding biometric characteristics and germination is an important component for the recovery of ecosystems, since seeds are the propagules most often used for such purposes. Among the variables analyzed in the present study, the biometric characteristics of both species were quite similar, however, there was differentiation in some physical characteristics, as in the number of seeds per kilo and in the weight of 1,000 seeds. Since the seed dimensions are similar, physical differences may be due to the water content at the time of analysis, which can be explained by changes in temperature and relative humidity of the air, causing constant adjustments in water content of the stored seeds and even resulting in differences between samples of the same species (CARVALHO; NAKAGAWA, 2012). For S. virgata, the observed biometric values were similar to those described by Araújo et al. (2004).

The morphological characteristics of seeds and development after germination are important characteristics that help increase knowledge about the autoecology of species, especially when it proposes natural regeneration of environments. S. punicea and S. virgata present morphological characteristics of pioneer species, such as small and light seeds that persist in the seed bank of the soil (TWEEDLE et al., 2003), as well as phanerocotyledonous, epigeal seedlings with foliaceous cotyledons, as described by Gogosz et al. (2015). The characteristics related to cotyledons provide advantages for competition and establishment in environments with high luminosity rates, since the rapid process of raising and opening of cotyledons favors the initial development of seedlings from the photosynthetic rate (RESSEL et al., 2004). During the germination process, the cotyledons 
in both species are free from the tegument, and are above the soil surface, being important characteristics for the morphological classification of the seedlings (BATTILANI et al., 2011).

Regarding the germination test, $S$. virgata presented a higher percentage of mean germination than $S$. punicea. Among the factors that support this difference, one can infer about aspects of overcoming dormancy, and $S$. punicea could possibly be more sensitive to the mechanical scarification of seeds, as all stages and treatments were applied equally and simultaneously to both species. In the study developed by Araújo et al. (2004), S. virgata showed mean germination of 52\% with the use of commercial substrate.

In the present work, optimum germination temperatures for S. punicea were $20^{\circ} \mathrm{C}$ and $25{ }^{\circ} \mathrm{C}$, and all evaluated temperatures were favorable for the germination process of $S$. virgata. When compiling several studies about ecological aspects related to optimum temperature for germination of 272 Brazilian tree species, Brancalion et al. (2010) concluded that $25^{\circ} \mathrm{C}$ can be considered the most favorable temperature for seed germination for most Atlantic forest species, followed by a temperature of $30^{\circ} \mathrm{C}$.

According to Marcos Filho (2015), each species presents an optimum temperature in which seeds will express the most efficient combination between germination speed and percentage of final germination, since temperature directly influences these characteristics. Therefore, this variable is extremely important for detecting climatic adaptations and niche amplitude (JIMENEZ-ALFARO et al., 2016), resulting in the number of seeds that will become seedlings and that may survive (SIMONS, 2009).

The most suitable substrate is one that provides the best moisture retention, aeration for seeds and lowest degree of infection by pathogens, allowing for the highest germination percentages and speeds (MIRANDA et al., 2012). Despite being from the same genus, the two species presented different performances regarding the substrates tested. For S. punicea seeds, the most efficient substrate was the blotting paper, which presented a higher germination percentage and shorter synchronization time. However, the most suitable substrate for the germination for S. virgata was vermiculite, which presented higher values compared to most of the variables evaluated in the experiment, favoring the uniformity and germination potential of the species.

The ample amount of information in the literature shows that seeds of forest species have distinct requirements of substrates used for germination (BOCCHESE et al., 2008). Such fact demonstrates the need for studies that aim to better understand the silviculture of each species, which can affect their maximum vigor and subsidize and assist in the production of seedlings used in forest restoration programs.

In degraded landscapes, where the dispersion processes are interrupted or habitats are isolated, the germination characteristics are just as important as information about dispersal types for the composition of plant communities. For restoration techniques, such as seed bank transposition or natural regeneration, it is essential that germination and seedling development characteristics are considered, since their descendants need to germinate and establish in an environment to ensure the recruitment of subsequent generations.

Thus, given the high germination rate and vigor of the seeds of both species, allied with their possible use in the recovery of ecosystems, the results of this work are indispensable for the success, use and understanding of the silviculture and ecology of native species.

\section{CONCLUSION}

- The morphological and biometric characteristics described in this work are relevant for taxonomic identification, as well as for the autoecology of the species, favoring both their silvicultural and ecological uses.

- For S. punicea, the blotting paper substrate and the temperature of $25{ }^{\circ} \mathrm{C}$ proved to be most efficient for germination. For S. virgata, all treatments proved to be effective for the germination of the species.

\section{ACKNOWLEDGMENTS}

To Franscico Tomo Arantes for all support with the images, to Coordenação de Aperfeiçoamento de Pessoal de Nível Superior (CAPES-Brazil) and to Conselho Nacional de Desenvolvimento Científico (CNPqBrazil) for the financial support. 


\section{REFERENCES}

ALLEN, O. N.; ALLEN, E. K. The Leguminosae: a source book of characteristics, uses and nodulation. University of Madison, Madison, EUA. 1981. 812 p.

ARAÚJO, E. C. MENDONÇA, A. V. R.; BARROSO, D. G.; LAMÔNICA, K. R.; SILVA, R. F. Caracterização morfológica de frutos, sementes e plântulas de Sesbania virgata (Cav.) Pers. Revista Brasileira de Sementes, Brasília, v. 26, n. 1, p. 105-110, 2004.

BATTILANI, J. L.; SANTIAGO, E. F.; SOUZA, A. L. T. D. Aspectos morfológicos de frutos, sementes e desenvolvimento de plântulas e plantas jovens de Unonopsis lindmanii Fries (Annonaceae). Acta Botanica Brasilica, Belo Horizonte, v. 21, n. 4, p. 897 - 907, 2007.

BOCCHESE R. A.; OLIVEIRA, A. K. M.; MELLOTO, A. M.; FERNANDES, V.; LAURA, V. A. Efeito de diferentes tipos de solos na germinação de sementes de Tabebuia heptaphylla, em casa telada. Cerne, Lavras, v. 14, n. 1, p. 62 - 67, 2008.

BRANCALION, P. H. S.; NOVEMBRE, A. D. D. L. C.; RODRIGUES, R. R. Temperatura ótima de germinação de sementes de espécies arbóreas brasileiras. Revista Brasileira de Sementes, Londrina, v. 32, n. 4 , p. $15-21,2010$.

BRASIL. Ministério da Agricultura, Pecuária e Abastecimento. Regras para análise de sementes. Secretaria de Defesa Agropecuária. Brasília, DF: Mapa/ACS, 2009. 395 p.

BUCKERIDGE, M. S.; MORTARI, L. C.; MACHADO, M. R. Respostas fisiológicas de plantas às mudanças climáticas: alterações no balanço de carbono nas plantas podem afetar o ecossistema? IN: REGO, G. M.; NEGRELlE. R. R. B; MORELLATO, L. P. C. Fenologia - Ferramenta para conservação e manejo de recursos vegetais arbóreos. Colombo, PR: Embrapa Florestas, 2007.

CARVALHO, N. M.; NAKAGAWA, J. Sementes: ciência, tecnologia e produção. 5.ed. FUNEP: Jaboticabal, 2012. $590 \mathrm{p}$.

FLORENTINO, L. A.; MOREIRA, F. M. S. Características simbióticas e fenotípicas de Azorhizobium doebereinerae, microissimbiote de Sesbania virgata. Revista Árvore, Viçosa, v. 33, n. 2, p. 215 - 226, 2009.

GOGOSZ, A. M.; BOERGER, M. R. T.; COSMO, N. L.; NOGUEIRA, A. C. Morfologia de diásporos e plântulas de espécies arbóreas da floresta com araucária, no sul do Brasil. Floresta, Curitiba, v. 45, n. 4, p. $819-832,2015$.

GONÇALVES, L. G. V.; ANDRADE, F. R.; JUNIOR, M.; HUR, B.; SCHOSSLER, T. R.; LENZA, E.; MARIMON, B. S. Biometria de frutos e sementes de mangaba (Hancornia speciosa Gomes) em vegetação natural na região leste de Mato Grosso, Brasil. Revista de Ciências Agrárias, Lisboa, v. 36, n. 1, p. 31 - 40, 2013.

GUEDES, R. A.; ALVES, E. U.; GONÇALVES, E. P.; BRUNO, R. L. A.; BRAGA JÚNIOR, J. M.; MEDEIROS, M. S. Germinação de sementes de Cereus jamacaru DC. em diferentes substratos e temperaturas. Acta Scientiarum. Biological Sciences, Maringá, v. 31, n. 2, p. 159 - 164, 2009.

HALISKI, S.; COSMO, N. L.; GOGOSZ, A. M.; REGO, S. S.; NOGUEIRA, A. C.; KUNIYOSHI, Y. S. Caracterização morfológica de frutos, sementes, plântulas e germinação de sementes de Casearia decandra. Pesquisa Florestal Brasileira, Colombo, v. 33, n. 75, p. 253 - 259, 2013.

JIMÉNEZ-ALFARO, Borja et al. Seed germination traits can contribute better to plant community ecology. Journal of Vegetation Science, v. 27, n. 3, p. 637-645, 2016.

LABORIAU, L. G. A germinação das sementes. Organização dos Estados Americanos, Washington, Estados Unidos, 1983. 174 p.

FLORESTA, Curitiba, PR, v. 49, n. 4, p. 661 - 670, out/dez 2019

Duarte, M. M. et.al.

ISSN eletrônico 1982-4688

DOI: $10.5380 /$ rf.v49 i4.57410 
MAGUIRE, J. D. Speed of germination-aid in selection and evaluation for seedling emergence and vigor. Crop Science, Madison, v. 2, n. 2, p. 176 - 177, 1962.

MARCOS FILHO, J. Fisiologia de sementes de plantas cultivadas. 2 ed. Londrina: ABRATES, 2015. 660p.

MIRANDA, C. C.; SOUZA, D. M. S.; MANHONE, P. R.; OLIVEIRA, P. C.; BREIER, T. B. Germinação de sementes de Anadenanthera peregrina (L.) Speg. com diferentes substratos em condições laboratoriais. Floresta e Ambiente, Seropédica, v. 19, n.1, p. 26 - 31, 2012.

MONDO, V. H. V.; BRANCALION, P. H. S.; CICERO, S. M.; NOVEMBRE, A. D. C.; DOURADO NETO, D. N. Teste de germinação de sementes de Parapiptadenia rigida (Benth.) Brenan (Fabaceae). Revista Brasileira de Sementes, Londrina, v. 30, n. 2, p. 177 - 183, 2008.

OLIVEIRA, L. M.; DAVIDE, A. C.; CARVALHO, M. L. M. Teste de germinação de sementes de Peltophorum dubium (Spregel) Taubert - Fabaceae. Floresta, Curitiba, v. 38, n. 3, p. 545 - 551, 2008.

POTOMATI, A.; BUCKERIDGE, M. S. Effect of abscisic acid on the mobilisation of galactomannan and embryo development of Sesbania virgata (Cav.) Pers. (Leguminosae-Faboideae). Revista Brasileira de Botânica, São Paulo, v. 25, n. 3, p. 303 - 310, 2002.

RESSEL, K.; GUILHERME, F. A. G.; SCHIAVINI, I.; OLIVEIRA, P. E. Ecologia morfofuncional de plântulas de espécies arbóreas da Estação Ecológica do Panga, Uberlândia, Minas Gerais. Revista Brasileira de Botânica, São Paulo v. 27, n. 2, p. 311 - 323, 2004.

RIOS, P. A. F.; NETO, J. C. A.; FERREIRA, V. M.; NEVES, M. I. R. S. Seed morphometry and germination of Aechmea costantinii (Mez) L.B. Sm. (Bromeliaceae). Revista Caatinga, Mossoró, v. 29, n. 1, p. 85 - 93, 2016.

SIMONS, Andrew M. Fluctuating natural selection accounts for the evolution of diversification bet hedging. Proceedings of the Royal Society of London B: Biological Sciences, v. 276, n. 1664, p. 1987-1992, 2009.

TWEDDLE, J. C. DICKIE, J. B.; BASKIN, C. C.; BASKIN, J. M. Ecological aspects of seed desiccation sensitivity. Journal of Ecology, Oxford, v. 91, n. 2, p. 291-304, 2003. 